\title{
Effect of Phosphorus Solubilizing Bacteria on Growth, Yield, Quality and Nutrient Uptake in Nanasaheb Purple Grapes Grown under Semi-Arid Condition
}

\author{
A. G. Swaminathan ${ }^{1}$, K. P. Hariprasad ${ }^{1}$, A. V. Suryawanshi ${ }^{1}$, \\ G. B. Kadam ${ }^{1}$ and Vilas S. Ghule ${ }^{2}$ \\ ${ }^{1}$ Embio Research Centre, Mahad (M.S.), India \\ ${ }^{2}$ M.P.K.V., Rahuri, India \\ *Corresponding author
}

A B S T R A C T

\section{Keywords \\ PSB, Nanasaheb Purple, Yield, quality, Nutrient uptake}

\section{Article Info}

Accepted:

11 June 2020

Available Online:

10 July 2020
The field experiment was conducted to study the effect of phosphorus solubilizing bacteria (PSB) on growth, yield, quality and nutrient uptake in Nanasaheb Purple grapes during 2018-19. The PSB product (Jaiv Shakti P) was drenched through soil at $30^{\text {th }}, 45^{\text {th }}$ and $60^{\text {th }}$ days after fruit pruning at a different concentration of $0.5,1,1.5,2$ and $2.5 \mathrm{ml} / \mathrm{vine}$. The observations on growth, yield, quality, nutrient uptake and microbial load at rhizosphere were studied at different stages of development was recorded. Growth and quality, berry biochemical, petiole nutrient content and microbial load showed significant difference to the various levels of PSB application. The positive correlation between PSB concentration and growth, yield, quality, nutrient and microbial characters was recorded in the present study.

\section{Introduction}

Grape (Vitis vinifera L.) is one of the major important fruit crops earning maximum foreign exchange. The area under grape cultivation during 2017-18 was 1.39 lakh hectares with production of 2920 million tonnes (Anonymous, 2018). Nanasaheb Purple is promising black seedless variety developed by clonal selection from Sharad Seedless grapes. It has high demand in domestic market due to its quality and attractive colour and it is being grown in four states viz. Maharashtra, Andhra Pradesh, Madhya Pradesh and Karnataka covering more than 21,000 hectares area (Anonymous, 2019). Berry development requires appropriate dosage of nutrients. Phosphorus is an important nutrient in producing the quality grape as it is also directly related to fruitfulness of vine. It is required mostly for plant growth in tropical areas due to its less availability in soil (Santana et al., 2016). The concentration ranges between $0.2-0.8 \%$ dry weight of the plant and it is mainly constituent of nucleic acids, enzymes, 
coenzymes, nucleotides, and phospholipids. Phosphorus is essential in each part of grapevine and its development, from the micro level to many physiological and biochemical plant activities including photosynthesis (Sharma et al., 2013). It is also actively responsible for root growth, cell enlargement, formation of flowers and seeds, crop maturity, quality of crop, energy production, storage, transfer reaction and showed resistance to many plant diseases (Sharma et al., 2013; Kumar and Patel, 2018; Khan et al., 2009; Satyaprakash et al., 2017; Walpola and Yoon, 2012 (a)).

Phosphorus is the second most important macronutrient required by the plants, next to nitrogen. At present, availability of soluble form of $\mathrm{P}$ for plants in the soil is limited because of its fixation as insoluble phosphates of iron, aluminium and calcium in soil (Walpola and Yoon, 2012 (b); Mehrvarz et al., 2008; Alam et al., 2002). About 75-90\% of the added chemical $\mathrm{P}$ fertilizer is precipitated by metalcation complexes and it becomes fixed in soils and has long term impact on the environment in terms of eutrophication, soil fertility depletion and carbon footprint (Sharma et al., 2013).

Microorganism which helps to solubilize insoluble phosphate are called as phosphate solubilizing microorganisms (PSMs). These are eco-friendly and helps in converting insoluble phosphate to soluble forms by acidification, chelation and exchange reaction (Zahoor et al., 2017). There are many strains of bacteria (Pseudomonas, Bacillus, Rhizobium, Enterobactor etc.) and fungi (Aspergillus and Penicillium) found to be as important phosphate solubilizes (Whitelaw, 2000; Peela et al.,2013). PSB not only provide $\mathrm{P}$ for growth of plant it also helps in increasing efficiency of $\mathrm{N}$ fixation and accelerate the accessibility of other trace elements by synthesizing essential growth promoting substances like siderophores, antibiotics etc. (Walpola and Yoon, 2012 (a); Hussain et al., 2013). Zahoor et al., (2017) found that PSB application in tomato significantly increase plant height, fruit yield and $\mathrm{P}(\%)$ in fruits over control. Purlak and Kose (2009) also reported that PSB application results in better yield, nutrition and plant growth enhancement in strawberry. Rolli et al., (2017) noted that application of PSB improved shoot length and shoot diameter in grapevines of Italy. Considering importance of PSB and its eco-friendly nature, the experiment was conducted to study the effect of phosphorous solubilizing bacteria on growth, yield, quality and nutrient uptake in Nanasaheb Purple grapes grown under semi-arid condition.

\section{Materials and Methods}

The trial was conducted at grower's field in Pune district during 2018-19. The experimental site is situated in Mid-West Maharashtra at an altitude of $527 \mathrm{~m}$ above mean sea level. The trial was conducted on three-year-old vineyard of Nanasaheb Purple grapes grafted on Dogridge rootstock and trained to bower system. The vines were spaced at 9 feet between two rows and 4 feet between vines. The prepared PSB product (Jaiv Shakti P) by Embio Ltd., Mahad, M.S.) was applied through soil drenching at $30^{\text {th }}$, $45^{\text {th }}$ and $60^{\text {th }}$ days after fruit pruning at a concentration of $0.5,1,1.5,2$ and $2.5 \mathrm{ml} /$ vine. The soil samples were collected in sterile polythene bags and brought into laboratory and stored at $4{ }^{\circ} \mathrm{C}$ for microbial analysis (Liu et al., 2016). The observations were recorded as below.

\section{Growth and yield parameters}

The growth parameters were recorded at $75^{\text {th }}$ days after fruit pruning. Shoot length was measured with the help of measuring tape and 
was expressed in $\mathrm{cm}$. Shoot diameter was measured with the help of digital Vernier Calliper and was expressed in $\mathrm{mm}$. Total chlorophyll $(\mathrm{mg} / \mathrm{g})$ and Leaf area $\left(\mathrm{cm}^{2}\right)$ were measured using leaf area meter (CIB, Inc).

The yield parameters such as bunches per vine were counted after berry setting and mean was recorded. Average bunch weight (g) was recorded by averaging five bunches. Number of berries per bunch was counted and mean was recorded. Fifty berry weight (g) was recorded with the help of weighing balance and yield per vine $(\mathrm{kg})$ was recorded at the time of harvesting.

\section{Quality parameters}

The quality parameters were recorded after harvesting. Berry length $(\mathrm{mm})$ and berry diameter $(\mathrm{mm})$ was recorded with the help of digital vernier calliper. The juice was extracted from berries using muslin cloth and TSS and acidity was estimated. Total soluble solids $\left({ }^{\circ} \mathrm{B}\right)$ were measured using a hand-held temperature-compensated digital refractometer (ERMA, Japan), while titratable acidity (g/lit) was measured titrating a known volume of juice with $0.1 \mathrm{~N} \mathrm{NaOH}$ using phenolphthalein as indicator.

\section{Biochemical parameters}

After the harvest, the whole berry was crushed and the sample was stored at $-20^{\circ} \mathrm{C}$ for further analysis. Total phenolic content $(\mathrm{mg} / \mathrm{g})$ was estimated using Folin-Ciocalteu reagent and by measuring the absorbance of the reaction mixture at $650 \mathrm{~nm}$ (Singleton and Rossi, 1965). Same samples were used for estimation of tannin $(\mathrm{mg} / \mathrm{g})$ and colour intensity (\%). The results obtained were expressed as catechol equivalent. Reducing sugars $(\mathrm{mg} / \mathrm{g})$ were estimated by using Dinitro salicylic Acid (DNSA) method (Miller, 1972).Estimation of carbohydrate (mg/g) was done by the Anthrone method (Hedge and Hofreiter, 1962). The anthocyanin (mg/lit) contents of the berry samples were analysed according to the method of Ticconi et al., (2001). Proline content (mg g $\mathrm{g}^{-1}$ ) was colorimetrically estimated as per the method of (Bates et al., 1973). Protein (mg/g) estimation was carried out by colorimetric method described by Lowry et al., (1951).

\section{Petiole nutrient content}

The petiole samples were drawn from field at $35^{\text {th }}, 45^{\text {th }}$ and $65^{\text {th }}$ days after fruit pruning. The collected petioles were washed with tap water followed by distilled water and then dried in oven. After drying, a fine powder was prepared and used for further nutrient analysis. The samples were dried at $70^{\circ} \mathrm{C}$, wet digested and analyzed for $\mathrm{N}$ by Kjeldahl method. Another part of the sample was digested with $\mathrm{HNO}_{3}: \mathrm{HClO}_{4}(9: 4 \mathrm{v} / \mathrm{v})$ and $\mathrm{P}$ was estimated by vanado-molybdate method. The sodium and potassium were analysed by ICP OES (Agilent Make, Model -5110 SVDV). Potassium and sodium were determined by flame photometer. An atomic absorption Spectrophotometer was used for determining $\mathrm{Ca}, \mathrm{Mg}$ and $\mathrm{Zn}$ in the absorption mode (Sharma et al., 2005).

\section{Microbial count}

The quantitative estimation of phosphate solubilisation by soil microflora was measured by vanadomolybdate phosphoric method (Jackson, 1985). One gm of soil sample collected from grapes rhizosphere was added in $9 \mathrm{ml}$ of distilled water, for each sample separately, vortexed and made up to $10^{-9}$ folds by serial dilution method. From the serially diluted samples, $0.1 \mathrm{ml}$ suspension was spreaded on Pikovskaya agar medium (Nautiyal, 1999) amended with tri calcium phosphate (TCP $5.0 \mathrm{~g} / \mathrm{L}$ ) as a sole source of $\mathrm{P}$ and incubated at $30^{\circ} \mathrm{C}$ for 7 days. The 
growing bacterial colonies formed clear hallow zone. These colonies were counted as a phosphate solubilising bacteria.

\section{Statistical analysis}

The experiment was conducted in randomizer block design. Data were analyzed using Minitab software, version 16.0. Comparison of means was made by Duncan's multiple range test $(\mathrm{P}-0.05)$. The data represented in figures are expressed as means of three biological replicated \pm standard deviation (SD).

\section{Results and Discussion}

\section{Growth parameters}

The data recorded on various growth parameters are presented in table. With the application of different concentrations of PSB, significant differences were recorded among the growth parameters. Highest shoot length $(92.06 \mathrm{~cm})$, shoot diameter $(8.43 \mathrm{~mm})$, total chlorophyll $(1.31 \mathrm{mg} / \mathrm{g})$ and leaf area $\left(178 \mathrm{~cm}^{2}\right)$ were recorded in PSB application of $2.5 \mathrm{ml} /$ vine treatment while lowest shoot length $(78.24 \mathrm{~cm})$, shoot diameter $(7.33 \mathrm{~mm})$, total chlorophyll (0.90) and leaf area (136.67 $\mathrm{cm}^{2}$ ) were recorded in control. Highest growth was noted in maximum concentration of PSB i.e. $2.5 \mathrm{ml} /$ vine and decline in growth was observed as concentration of PSB decreased. Positive correlation between PSB concentration and growth of vine was noted in the present study. From the above results it can be stated that application of PSB significantly changes the growth of vine and higher concentration of PSB results better growth of vine. This might be due to the production of auxin by PSB and increased supply of phosphorus by PSB (Fankem et al., 2008). Also the increase in growth characters might be due to stimulative effect of PSB on $\mathrm{P}$ solubilisation leading to higher $\mathrm{P}$ availability and uptake by plants as reported by Sharma et al., (2007) and Turan et al., (2007). Zahoor et al., (2017) reported improved growth characteristics by application of PSB in Tomato and Rolli et al., (2017) noted improving shoot length and shoot diameter in grapevines of Italy.

\section{Yield parameters}

The yield parameters such as bunches per vine and number of berries per bunch showed non-significant effect on PSB application in the vineyard as the bunches per vine and number of berries per bunch are maintained keeping in view of export. Parameters like average bunch weight, 50 berry weight and yield/vine showed significant effect to PSB application. Highest average bunch weight $(663.67 \mathrm{~g}), 50$ berry weight $(458.0 \mathrm{~g})$ and yield $(17.38 \mathrm{~kg})$ were recorded in PSB application of $2.5 \mathrm{ml} /$ vine while lowest average bunch weight (513.63 g), 50 berry weight $(355.0 \mathrm{~g})$ and yield $(13.53 \mathrm{~kg})$ were noted in control (No PSB application). Increase in average bunch weight, 50 berry weight and yield were observed as concentration of PSB application/vine (0.5, 1.0, 1.5, 2.0 and $2.5 \mathrm{ml} /$ vine) increased. The positive correlation was observed between the PSB concentration and yield parameters. Availability of $\mathrm{P}$ and its active participation in shoot and root growth led to better plant growth, which later translated into higher yield attributes and resultant yield of grapes. The increase in fruit yield with inoculation of $\mathrm{P}$ solubilizing microorganisms might be due to increase in $\mathrm{P}$ availability through solubilization of insoluble inorganic phosphate by organic acid, decomposition of phosphate-rich organic compounds and production of plant growth promoting substances (Gaur and Sunita, 1999). Microorganisms enhance the $\mathrm{P}$ availability to plants by mineralizing organic $\mathrm{P}$ in soil and by solubilizing precipitated phosphates (Chen 
et al., 2006).Similar results were reported in tomato (El-Tantawy and Mohamed, 2009; Poonia and Dhaka, 2012).

\section{Quality parameters}

Application of PSB to the vine showed positive effect on grape quality parameters. Berry length, berry diameter, TSS and acidity varied significantly among different concentration of PSB. Berry length was increased from 19.33 to $22.67 \mathrm{~mm}$ while the berry diameter was increased from 18.33to $23.33 \mathrm{~mm}$ with the increase in concentration of PSB from 0.5 to $2.5 \mathrm{ml} / \mathrm{vine}$ respectively. The treatment T3 (1ml PSB/vine) recorded highest TSS $\left(18.67{ }^{\circ} \mathrm{B}\right)$ and lowest acidity $(5.50 \mathrm{~g} /$ lit. $)$ while lowest TSS $\left(18.20^{\circ} \mathrm{B}\right)$ and highest acidity $(5.55 \mathrm{~g} /$ lit.) were observed in $\mathrm{T}_{1}$ (control).

\section{Biochemical parameters}

Biochemical parameters like phenol, total tannin, colour intensity, reducing sugar, carbohydrates, anthocyanin, proline and protein studied in the present experiment are presented in table. Application of PSB resulted in significant variation in biochemical content. Phenol content was highest $(3.67 \mathrm{mg} / \mathrm{g})$ in $\mathrm{T}_{5}(2.0 \mathrm{ml} \mathrm{PSB} / \mathrm{vine})$, colour intensity was maximum $(2.60 \%)$ in $\mathrm{T}_{4}$ (1.5 ml PSB/vine). Reducing sugar (103.57 $\mathrm{mg} / \mathrm{g})$ and proline $(8.81 \mu$ moles $)$ were higher in $\mathrm{T}_{3}$ (1.0 ml PSB/vine). Total tannin (4.01 $\mathrm{mg} / \mathrm{g})$, anthocyanin (476.12 $\mathrm{mg} / \mathrm{lit}$.) and protein $(9.69 \mathrm{mg} / \mathrm{g})$ were observed in $\mathrm{T}_{6}(2.5$ $\mathrm{ml} \mathrm{PSB/vine)} \mathrm{while} \mathrm{lowest} \mathrm{phenol} \mathrm{(2.07}$ $\mathrm{mg} / \mathrm{g})$, total tannin $(2.27 \mathrm{mg} / \mathrm{g})$, colour intensity (1.51\%), reducing sugar (66.33 $\mathrm{mg} / \mathrm{g})$, anthocyanin $(218.52 \mathrm{mg} / \mathrm{lit}$.$) , proline$ $(5.50 \mu$ moles $)$ and protein $(5.66 \mathrm{mg} / \mathrm{g})$ were recorded lowest in $\mathrm{T}_{1}$ (control). From the above results it can be stated that PSB application significantly affects the biochemical content of berries as compared to control. The variation in biochemical content might be due to the $\mathrm{P}$ uptake that has resulted in quick metabolic transformation of starch to pectin into soluble compounds and rapid translocation of sugars from leaves to the developing berries (Mishra and Tripathi, 2011).The findings of the present investigations are in agreement with the result of Singh et al., (2009) in ber, Baksh et al., (2008) in guava, Mishra and Tripathi (2011) in strawberry.

Table.1 Effect of PSB on growth parameters

\begin{tabular}{|c|c|c|c|c|}
\hline Treatments & $\begin{array}{c}\text { Shoot length } \\
(\mathbf{c m})\end{array}$ & $\begin{array}{c}\text { Shoot } \\
\text { diameter } \\
(\mathbf{m m})\end{array}$ & $\begin{array}{c}\text { Total } \\
\text { Chlorophyll } \\
(\mathbf{m g} / \mathbf{g})\end{array}$ & $\begin{array}{c}\text { Leaf area } \\
\text { (cm2) }\end{array}$ \\
\hline T1 (Control) & 78.24 & 7.33 & 0.90 & 136.67 \\
\hline T2 & 80.35 & 7.70 & 1.07 & 140.00 \\
\hline T3 & 83.62 & 7.87 & 1.14 & 154.00 \\
\hline T4 & 86.31 & 8.30 & 1.23 & 165.33 \\
\hline T5 & 91.07 & 8.43 & 1.30 & 175.00 \\
\hline T6 & 92.06 & 8.43 & 1.31 & 178.00 \\
\hline SEm $\mathbf{C D}$ at 5\% & 0.38 & 0.03 & 0.02 & 0.67 \\
\hline Sig. & 1.15 & 0.10 & 0.06 & 2.02 \\
\hline
\end{tabular}


Table.2 Effect of PSB on yield parameters

\begin{tabular}{|c|c|c|c|c|c|}
\hline Treatment & $\begin{array}{c}\text { Bunches/ } \\
\text { vine }\end{array}$ & $\begin{array}{c}\text { Average } \\
\text { bunch } \\
\text { weight (g) }\end{array}$ & $\begin{array}{c}\text { No. of } \\
\text { berries per } \\
\text { bunch }\end{array}$ & $\begin{array}{c}\text { 50 berries } \\
\text { weight (g) }\end{array}$ & $\begin{array}{c}\text { Yield/vine } \\
\text { (kg) }\end{array}$ \\
\hline T1 (Control) & 26.33 & 513.67 & 73.00 & 355.00 & 13.53 \\
\hline T2 & 27.00 & 529.33 & 72.33 & 364.67 & 14.30 \\
\hline T3 & 26.00 & 556.33 & 73.66 & 375.00 & 14.47 \\
\hline T4 & 27.00 & 602.00 & 72.66 & 432.67 & 16.25 \\
\hline T5 & 26.00 & 660.00 & 71.66 & 453.67 & 17.26 \\
\hline T6 & 26.33 & 663.67 & 72.33 & 458.00 & 17.38 \\
\hline SEm \pm & 0.31 & 3.55 & 0.59 & 3.41 & 0.23 \\
\hline CD at 5\% & 0.94 & 10.70 & 1.79 & 10.26 & 0.69 \\
\hline Sig. & NS & $* *$ & NS & $* *$ & $* *$ \\
\hline
\end{tabular}

Table.3 Effect of PSB on quality parameters

\begin{tabular}{|c|c|c|c|c|}
\hline Treatment & $\begin{array}{c}\text { Berry diameter } \\
(\mathbf{m m})\end{array}$ & $\begin{array}{c}\text { Berry length } \\
(\mathbf{m m})\end{array}$ & TSS $\left(\mathbf{(}^{\mathbf{B}} \mathbf{B r i x}\right)$ & Acidity (g/lit) \\
\hline T1 (Control) & 18.33 & 19.33 & 18.20 & 5.55 \\
\hline T2 & 19.67 & 19.67 & 18.23 & 5.52 \\
\hline T3 & 21.33 & 20.00 & 18.67 & 5.50 \\
\hline T4 & 22.33 & 20.67 & 18.43 & 5.51 \\
\hline T5 & 23.67 & 22.67 & 18.33 & 5.53 \\
\hline T6 & 23.33 & 22.67 & 18.23 & 5.55 \\
\hline SEm \pm & 0.23 & 0.30 & 0.02 & 0.01 \\
\hline CD at 5\% & 0.70 & 0.90 & 0.07 & 0.02 \\
\hline Sig. & $* *$ & $* *$ & $* *$ & $* *$ \\
\hline
\end{tabular}

Table.4 Effect of PSB on biochemical quality parameters

\begin{tabular}{|c|c|c|c|c|c|c|c|c|}
\hline Treatments & $\begin{array}{c}\text { Phenol } \\
(\mathbf{m g} / \mathbf{g})\end{array}$ & $\begin{array}{c}\text { Total } \\
\text { Tannin } \\
(\mathbf{m g} / \mathbf{g})\end{array}$ & $\begin{array}{c}\text { Colour } \\
\text { intensity } \\
(\mathbf{\%})\end{array}$ & $\begin{array}{c}\text { Reducing } \\
\mathbf{s u g a r} \\
(\mathbf{m g} / \mathbf{g})\end{array}$ & $\begin{array}{c}\text { Carbohy } \\
\mathbf{d r a t e s} \\
(\mathbf{m g} / \mathbf{g})\end{array}$ & $\begin{array}{c}\text { Anthocy } \\
\text { anin } \\
(\mathbf{m g} / \mathbf{l i t} \mathbf{)})\end{array}$ & $\begin{array}{c}\text { Proline } \\
(\boldsymbol{\mu m o l e s})\end{array}$ & $\begin{array}{c}\text { Protein } \\
(\mathbf{m g} / \mathbf{g})\end{array}$ \\
\hline T1 (Control) & 2.07 & 2.270 & 1.513 & 66.33 & 375.822 & 218.52 & 5.500 & 5.66 \\
\hline T2 & 2.07 & 3.274 & 2.071 & 71.70 & 371.433 & 315.43 & 7.800 & 6.87 \\
\hline T3 & 3.09 & 3.402 & 2.450 & 103.57 & 373.797 & 467.57 & 8.180 & 6.73 \\
\hline T4 & 3.40 & 3.674 & 2.607 & 92.42 & 372.380 & 470.19 & 6.475 & 9.00 \\
\hline T5 & 3.67 & 3.975 & 1.821 & 67.75 & 373.100 & 475.58 & 6.127 & 9.59 \\
\hline T6 & 3.66 & 4.013 & 1.922 & 67.46 & 373.557 & 476.12 & 6.247 & 9.69 \\
\hline S Em \pm & 0.01 & 0.02 & 0.01 & 0.31 & 0.29 & 0.58 & 0.06 & 0.02 \\
\hline CD at 5\% & 0.02 & 0.05 & 0.03 & 0.92 & 0.88 & 1.74 & 0.18 & 0.07 \\
\hline Sig. & $* *$ & $* *$ & $* *$ & $* *$ & $* *$ & $* *$ & $* *$ & $* *$ \\
\hline
\end{tabular}


Table.5 Effect of PSB on petiole nutrient status 35 DAP

\begin{tabular}{|c|c|c|c|c|c|c|c|}
\hline Treatments & $\mathbf{N}(\boldsymbol{\%})$ & $\mathbf{P ( \% )}$ & $\mathbf{K}(\boldsymbol{\%})$ & $\mathbf{N a}(\boldsymbol{\%})$ & $\mathbf{C a}(\boldsymbol{\%})$ & $\mathbf{M g}(\boldsymbol{\%})$ & $\mathbf{Z n}(\mathbf{p p m})$ \\
\hline T1 (Control) & 1.46 & 0.66 & 2.17 & 0.92 & 0.44 & 0.43 & 167.4 \\
\hline T2 & 1.46 & 0.73 & 2.27 & 0.15 & 0.68 & 0.30 & 186.2 \\
\hline T3 & 0.90 & 0.73 & 1.84 & 0.22 & 0.49 & 0.25 & 168.1 \\
\hline T4 & 1.18 & 0.71 & 1.71 & 0.24 & 0.54 & 0.32 & 203.8 \\
\hline T5 & 1.18 & 0.73 & 1.81 & 0.32 & 0.54 & 0.31 & 182.5 \\
\hline T6 & 1.23 & 0.72 & 2.13 & 0.17 & 0.68 & 0.29 & 161.2 \\
\hline
\end{tabular}

Table.6 Effect of PSB on petiole nutrient status 65 DAP

\begin{tabular}{|c|c|c|c|c|c|c|c|}
\hline Treatments & $\mathbf{N}(\mathbf{\%})$ & $\mathbf{P}(\boldsymbol{\%})$ & $\mathbf{K}(\boldsymbol{\%})$ & $\mathbf{N a}(\boldsymbol{\%})$ & $\mathbf{C a}(\boldsymbol{\%})$ & $\mathbf{M g}(\boldsymbol{\%})$ & $\mathbf{Z n}(\mathbf{p p m})$ \\
\hline T1 (Control) & 0.90 & 0.44 & 4.02 & 0.10 & 1.17 & 0.75 & 51.35 \\
\hline T2 & 0.76 & 0.60 & 3.42 & 0.07 & 0.89 & 0.54 & 30.68 \\
\hline T3 & 0.87 & 0.57 & 3.82 & 0.11 & 1.32 & 0.72 & 49.25 \\
\hline T4 & 0.92 & 0.52 & 4.45 & 0.08 & 1.29 & 0.75 & 51.40 \\
\hline T5 & 0.98 & 0.53 & 4.12 & 0.11 & 1.33 & 0.80 & 56.38 \\
\hline T6 & 0.92 & 0.55 & 2.72 & 0.11 & 1.26 & 0.68 & 44.93 \\
\hline
\end{tabular}

Table.7 Effect of PSB on microbial load: million CFU/gm of soil

\begin{tabular}{|c|c|c|c|c|c|c|}
\hline Description & $\mathbf{T}_{\mathbf{1}}(\mathbf{C o n} \mathbf{n} \mathbf{m})$ & $\mathbf{T}_{\mathbf{2}}$ & $\mathbf{T}_{\mathbf{3}}$ & $\mathbf{T}_{\mathbf{4}}$ & $\mathbf{T}_{\mathbf{5}}$ & $\mathbf{T}_{\mathbf{6}}$ \\
\hline Before application & 0.2 & 0.1 & 0.3 & 0.2 & 0.1 & 0.3 \\
\hline 30 days & 0.6 & 0.8 & 0.8 & 0.9 & 1 & 1.2 \\
\hline $\mathbf{4 5}$ days & 3 & 3.1 & 3.4 & 3.7 & 3.8 & 4.1 \\
\hline $\mathbf{6 0}$ days & 4.2 & 4.9 & 5.6 & 5.9 & 6.7 & 7.2 \\
\hline $\mathbf{7 5}$ days & 5.2 & 5.8 & 6.8 & 6.3 & 7.2 & 7.4 \\
\hline At harvest & 2.9 & 3.2 & 3.3 & 3.4 & 3.4 & 3.5 \\
\hline
\end{tabular}

\section{Nutrient uptake}

At 65 DAP N (0.98\%), Ca (1.33\%), Mg $(0.80 \%)$ and $\mathrm{Zn}(56.38 \mathrm{ppm})$ were observed in $\mathrm{T}_{5}(2.0 \mathrm{ml} \mathrm{PSB} / v i n e)$. Maximum $\mathrm{Na}(0.11$ $\%)$ was noted in $\mathrm{T}_{3}(1.0 \mathrm{ml} \mathrm{PSB} / \mathrm{vine}), \mathrm{T}_{5}(2.0$ $\mathrm{ml} \mathrm{PSB} /$ vine $)$ and $\mathrm{T}_{6}(2.5 \mathrm{ml} \mathrm{PSB} /$ vine $)$ treatments whereas, $\mathrm{P}(0.60 \%)$ and $\mathrm{K}(4.45$ $\%)$ were observed higher in $\mathrm{T}_{5}(2.0 \mathrm{ml}$ $\mathrm{PSB} / \mathrm{vine})$ and $\mathrm{T}_{4}(1.5 \mathrm{ml} \mathrm{PSB} / \mathrm{vine})$. While lowest N (0.76 \%), Na (0.07\%), Ca (0.89\%), $\mathrm{Mg}(0.54 \%)$ and $\mathrm{Zn}$ (30.68 ppm) were recorded in T2 $(0.5 \mathrm{ml} \mathrm{PSB} / \mathrm{vine})$. Whereas, lowest P (0.44 \%) and $\mathrm{K}(2.72 \%)$ were recorded in $\mathrm{T} 1$ and $\mathrm{T} 2$ respectively. The above results clearly indicated that application of PSB not only increased $\mathrm{P}$ level but also helped in improving uptake of other nutrients. This might be due to the phosphorus solubilizing bacteria (PSB) helped in growth of plants by stimulating the efficiency of biological nitrogen fixation, synthesizing phytohormones and enhancing the availability of some trace elements such as zinc and iron (Wani et al., 2007). 


\section{Microbial load}

Microbial growth around the rhizosphere is important for healthy crop and also for better nutrient uptake. In this investigation microbial count of soil was measured at 30, 45, 60, 75 DAP and at harvest stage where PSB application is applied. From the results it is observed that PSB application treatment showed the microbial count $0.3 \mathrm{CFU} / \mathrm{gm}$ soil to $3.5 \mathrm{CFU} / \mathrm{gm}$ soil from the $30^{\text {th }}, 45^{\text {th }}, 60^{\text {th }}$ after application to harvest stage respectively. Microbial count showed significant changes among shift PSB application. This was mainly due to the purity of PSB and CFU count is to be maintained at recommended level. Which results increasing microbial activity at rhizosphere.

From the study it was concluded that $\mathrm{T}_{5}$ and $\mathrm{T}_{6}$ treatments were at par with each other. Nanasaheb Purple grapes showed better performance to PSB application (Jaiv Shakti P). All the parameters such as growth, yield, quality and nutrient uptake showed positive effect to PSB. Application of PSB increases growth, improves quality, nutrient uptake, microbial growth at rhizosphere as compared to control. From the above investigation it can be stated that PSB application at a concentration of $2.0 \mathrm{ml} / \mathrm{vine}$ was proved to be the best for Nanasaheb Purple grapes.

\section{References}

Anonymous. 2018. Horticulture statistics at a glance, 2018.

Anonymous. 2019. National innovation foundation Govt. of India.

Alam, S., Khalil, S., Ayub, N. and Rashid, M. 2002.In vitro solubilisation of inorganic phosphate by phosphate solubilizing microorganism (PSM) from maize rhizosphere. International Journal of Agricultural Biology, 4: 454-458.

Baksh, H., Yadav, R. and Dwivedi, R. 2008.
Effect of INM on growth, yield attributing characters and quality of guava cv. Sardar. Progressive Agriculture, 8(2): 141-144.

Bates, L.S., Waldren, R.P. and Teare, I.D. 1973. Rapid determination of free proline for water-stress studies. Plant Soil, 39: 205-207.

Chen, Y. P., Rekha, P. D., Arunshen, A. B., Lai, W. A. and Young, C. C. 2006. Phosphate solubilizing bacteria from subtropical soil and their tricalcium phosphate solubilizing abilities. Applied Soil Ecology, 34: 33-41.

El-Tantawy, M.E. and Mohamed, M.A.N. 2009. Effect of inoculation with phosphate solubilizing bacteria on the tomato rhizosphere colonization process, plant growth and yield under organic and inorganic fertilization. Journal of Applied Sciences Research, 5: 1117-1131.

Fankem, H., Laurette, N.N., Annette, D., John, Q., Wolfgang, M., FrancoisXavier, E. and Dieudonne, N. 2008. Solubilization of inorganic phosphates and plant growth promotion by strains of Pseudomonas fluorescens isolated from acidic soils of Cameroon. African Journal of Microbiology Research, 2: 171-178.

Gaur, A.C. and Sunita, G. 1999. Phosphate solubilizing microorganisms - An overview. Current Trends in Life Science, 23: 151-164.

Hedge, J. E., and Hofreiter, B. T. 1962. Methods. In: R. L. Whistler and J.N. Be Miller (eds.). Carbohydrate chemistry, p. 17, Academic Press, New York.

Hussain, M.H., Asghar, H.N., Akhtar, M.J. and Arshad, M. 2013. Impact of phosphate solubilizing bacteria on growth and yield of maize. Soil Environment, 32: 71-78.

Khan, A., Jilani, V., Akhtar, M. S., Naqvi, S. M. S. and Rasheed, M. 2009. 
Phosphorus solubilizing bacteria: occurrence, mechanisms and their role in crop production. Journal of Agricultural and Biological Science, 1:48-58.

Kumar, A. and Patel, H. 2018. Role of microbes in phosphorus availability and acquisition by plants. International Journal of Current Microbiology and Applied Sciences, 7(5):1344-1347.

Lowry, O. H., Rosenbrough, N. J. Farr, A. L. and Randall, R. J. 1951. Protein measurement with the folin phenol reagent. J. Biol. Chem. 193(1):265-275.

Mehrvarz,S.,Chaichi,M. R. and Alikhani, H. A.2008. Effects of phosphate solubilizing microorganisms and phosphorus chemical fertilizer on yield and yield components of barely (Hordeum vulgare L.).AmericanEurasian Journal of Agricultural and Environmental Science, 3: 822-828.

Miller, G.L. 1972. Use of Dinitrosalicylic acid reagent for determination of reducing sugars. Anal. Chem. 31:426428.

Mishra, A.N. and Tripathi, V.K. 2011. Influence of different Levels of Azotobacter, PSB alone and in combination on vegetative growth, flowering, yield and quality of strawberry cv. Chandler. International Journal of Applied Agricultural Research, 6 (3):203-210.

Nautiyal, C. S. (1999). An efficient microbiological growth medium for screening phosphate solubilizing microorganisms. FEMS Microbiol. Lett.170:265-270.

Peela, S., Kadiri, D.D., Gorle, N. and Peetala, K.V.R. 2013. Isolation, screening and identification of phosphate solubilizing bacteria from different regions of Visakhapatnam and Araku valley. International Journal of Advanced Biotechnology and Research, 4: 518-
526.

Prrlak, L. and Kose, M. (2009).Effects of plant growth promoting rhizobacteria on yield and some fruit properties of strawberry, Journal of Plant Nutrition, 32:7, 1173-1184.

Poonia, M.K. and Dhaka, B.L. 2012.Effect of phosphorus solublizing bacteria (PSB) on growth and yield in tomato. Journal of Horticultural Science, 1: 104-107.

Rolli, E., Marasco, R., Saderi, S., Corretto, E. et al., 2017. Root-associated bacteria promote grapevine growth: from the laboratory to the field. Plant Soil, 410:369-382.

Santana, E. B., Marques, E. L. S. and Dias, J. C. T. 2016. Effects of phosphatesolubilizing bacteria, native microorganisms and rock dust on Jatropha curcas L. growth. Genetics and Molecular Research, 15 (4).

Satyaprakash, M., Nikitha, T., Reddi, E. U. B., Sadhana, B. and Vani, S. S. 2017. A review on phosphorous and phosphate solubilising bacteria and their role in plant nutrition. International Journal of Current Microbiology and Applied Sciences, 6: 2133-2144.

Sharma, J., Shikhamany, S. D., Singh, R. K. and Raghupathi, H.B. 2005. Diagnosis of Nutrient Imbalance in Thompson Seedless Grape Grafted on Dog Ridge Rootstock by DRIS. Communications in Soil Science and Plant Analysis, 36: 2823-2838.

Sharma, K., Dak, G., Agrawal, A., Bhatnagar, M. and Sharma, R. 2007. Effect of phosphate solubilizing bacteria on the germination of Cicer arietinum seeds and seedling growth. Journal of Herbal Medicine and Toxicology, 1: 61-63.

Sharma, S. B., Sayyed, R. Z., Trivedi, M. H. and Gobi, T. A.2013. Phosphate solubilizing microbes: sustainable approach for managing phosphorus deficiency in agricultural soils. Springer 
Plus, 2: 587.

Singh, M., Singh, H.K. and Singh, J.K. 2009. Effect of INM on yield and quality of ber. cv. Banarsi Karaka. Asian Journal of Horticulture, 4 (1): 47-49.

Singleton, V. L. and Rossi, J. A. 1965. Colorimetry of total phenolics with phosphomolybdic-phosphotungstic acid reagents. Am. J. Enol. Vitic. 16:144158.

Ticconi, C. A., Delatorre, C. A. and Abel, S. 2001. Attenuation of phosphate starvation responses by phosphite in Arabidopsis. Plant Physiol. 127(3): 963-972.

Turan, M. Ataoglu, N. and Sahin, F. 2007. Effect of Bacillus FS-3 on growth of tomato (Lycopersicon esculentum L.) plant and availability of phosphorus in soil. Plant Soil Environment, 53: 58-64.

Walpola, B. C and Yoon, M. 2012 (a). Prospectus of phosphate solubilizing microorganisms and phosphorus availability in agricultural soils: a review. African Journal of
Microbiology Research, 6: 6600-6605.

Walpola, B.C. and Yoon, M. 2012 (b).

Isolation and characterization of phosphate solubilizing bacteria and their co-inoculation efficiency on tomato plant growth and phosphorous uptake. African Journal of Microbiology Research, 7: 266-275.

Wani, P. A., Khan, M. S., and Zaidi, A. (2007). Co-inoculation of nitrogen fixing and phosphate solubilizing bacteria to promote growth, yield and nutrient uptake in chickpea. ActaAgron. Hung., 55: 315-323.

Whitelaw, M.A. 2000. Growth promotion of plants inoculated with phosphate solubilizing fungi. Advances in Agronomy, 69: 99-151.

Zahoor, A.B., Sheikh, T., Fozia, S.W. and Basharat, H. 2017. Impact of phosphate solubilizing bacteria and inorganic fertilizers on yield attributes of tomato. Int. J. Curr. Microbiol. App. Sci. 6(6): 3233-3239.

\section{How to cite this article:}

Swaminathan, A. G., K. P. Hariprasad, A. V. Suryawanshi, G. B. Kadam and Vilas S. Ghule. 2020. Effect of Phosphorus Solubilizing Bacteria on Growth, Yield, Quality and Nutrient Uptake in Nanasaheb Purple Grapes Grown under Semi-Arid Condition. Int.J.Curr.Microbiol.App.Sci. 9(07): 1274-1283. doi: https://doi.org/10.20546/ijcmas.2020.907.146 